\title{
IMPLEMENTASI PRINSIP KEBEBASAN BERAGAMA DAN BERKEYAKINAN DI INDONESIA (Studi Kasus: Tanggung Jawab Negara dalam Konflik Sampang, Madura)
}

\author{
Rizky Adi Pinandito \\ Dosen Unissula \\ rizkyadi@unissula.ac.id
}

\begin{abstract}
The purpose of this study is to explain in depth how the responsibility of the state c.q Government of Indonesia against violations of the principle of freedom of religion in the case of Sampang, Madura. The method of approach used in this research is normative juridical in discussing the issue of implementation of protection and guarantee to freedom of religion and belief which is regulated in constitution and Indonesian legislation system and how state responsibility to religious conflict happened in Sampang, Madura, Jawa East. The results of the research conducted in the case of Sampang are, the security forces do not act or do omission (omission) in the event of riots. In addition, the government's attitude that provoked provocation was shown by the MUI who issued a decree stating that the Shia taught by Tajul Muluk is heretical. The State should (in this case the Police) take precautions. Therefore, the State c.q The Government of Indonesia is obliged to provide compensation, restitution and rehabilitation to victims of human rights violations as well as to give legal assertiveness to all perpetrators of riots including government officials who allow the riots of human rights violations. $T$
\end{abstract}

Keywords: Human Rights, Freedom of religion and belief, Government Responsibility

\begin{abstract}
Abstrak
Tujuan dari penelitian ini adalah untuk menjelaskan secara mendalam tentang bagaimana tanggung jawab negara c.q Pemerintah Indonesia terhadap pelanggaran prinsip kebebasan beragama dalam kasus Sampang, Madura. Metode pendekatan yang digunakan dalam penelitian ini adalah yuridis normatif dalam membahas permasalahan pelaksanaan perlindungan dan penjaminan terhadap kebebasann beragama dan berkeyakinan yang diatur di dalam konstitusi dan sistem perundang-undangan Indonesia serta bagaimana tanggung jawab negara terhadap konflik agama yang terjadi di daerah Sampang, Madura, Jawa Timur. Hasil dari penelitian yang dilakukan dalam kasus Sampang adalah, aparat keamanan tidak bertindak atau melakukan pembiaran (omission) pada saat terjadi kerusuhan. Selain itu, sikap pemerintah yang memicu provokasi ditunjukkan oleh MUI yang mengeluarkan keputusan yang menyatakan Syiah yang diajarkan oleh Tajul Muluk adalah sesat. Seharusnya Negara (dalam hal ini Kepolisian) melakukan tindakan pencegahan. Oleh karena itu, Negara c.q Pemerintah Indonesia berkewajiban untuk memberikan kompensasi, restitusi, dan rehabilitasi pada korban pelanggaran HAM serta memberi ketegasan hukum kepada semua pelaku kerusuhan termasuk aparat pemerintah yang membiarkan terjadinya kerusuhan pelanggaran HAM tersebut.
\end{abstract}

Kata kunci: HAM, Kebebasan beragama dan berkeyakinan, Tanggung jawab Pemerintah.

\section{A. PENDAhUluAN}

Hak asasi manusia (selanjutnya disebut dengan HAM) dapat berasal dari berbagai sumber baik dari ajaran agama, budaya, atau sifat dasar suatu masyarakat tertentu.
Jika melihat sejarahnya, HAM internasional banyak dipengaruhi oleh budaya masyarakat di negara-negara barat yang lebih mengedepankan hak-hak sipil dan politik dari individu-individu di dalam suatu negara. Hak-hak tersebut 
cenderung membatasi kekuasaan negara terhadap masyarakatnya, seperti hak individu untuk berekspresi, beragama, berserikat atau berkumpul, untuk berafiliasi dengan partai politik tertentu atau untuk ikut serta didalam sistem pemerintah. ${ }^{1} \mathrm{HAM}$ (human rights) diartikan secara universal sebagai "those rights which are inherent in our nature and without which we cannot live as human being" oleh masyarakat di dunia, ${ }^{2}$ karena HAM mempunyai dimensi yang sama dimanapun manusia itu berada. Sifat HAM adalah universal, artinya bahwa hak tersebut tidak saja harus diberikan kepada semua individu melainkan juga ada kewajiban universal bagi seluruh individu untuk memperlakukan dengan baik individu-individu yang kehilangan haknya. ${ }^{3}$

Di dalam instrumen hukum Internasional, terdapat HAM yang diakui sebagai hak yang absolute. Hak absolute adalah hak yang tidak dapat dibatasi oleh apapun, kapanpun dan dimanapun. Sedangkan hak non-absolute adalah hak yang dapat diberi batasan dan pelarangan selama alasan-alasan pelarangan tersebut merupakan kepentingan penegakan hukum. Hak absolute dikenal juga dengan istilah non-derogable rights yang artinya bahwa hak tersebut tidak dapat dibatasi dalam kondisi apapun meskipun dalam situasi yang mengancam keutuhan suatu negara. ${ }^{4}$ Hak bebas untuk berpendapat, beragama, dan berkeyakinan tertuang dalam Pasal 18 International Covenant on Civil and Political Rights (ICCPR). Kebebasan untuk memeluk agama dan kepercayaan juga tercantum di dalam Pasal 2 dan Pasal 18 Universal Declaration of Human Rights (UDHR) Tahun 1948 yang mengatur mengenai hak dan kebebasankebebasan tanpa perkecualian apapun, seperti ras, warna kulit, jenis kelamin, bahasa, agama, politik atau pendapat yang berlainan, asal mula kebangsaan atau kemasyarakatan, hak milik,

1 Al Khanif . Hukum dan Kebebasan Beragama Di Indonesia. (Yogyakarta: LaksBang Mediatama), 2010. hlm. 80

2 Muladi.,. Hak Asasi Manusia, Politik Dan Sistem Peradilan Pidana. (Semarang: Badan Penerbit Universitas Diponegoro), 1997. hlm.1

3 Al Khanif, op.cit., hlm. 81

4 Rachel Ball, "Absolute and Non-Derogable Rights in International Law", Human Rights Law Centre, 2011, hlm. 1 kelahiran ataupun kedudukan lain. ${ }^{5}$

Di Indonesia, ideologi Pancasila serta ketentuan konstitusinya sudah menyadari akan pentingnya kebebasan memeluk agama dan berkeyakinan untuk warga negaranya. Pancasila sebagai ideologi negara Republik Indonesia telah merepresentasikan semangat jaman yang ada pada masa pasca kemerdekaannya. Tidak dijadikannya agama tertentu oleh para pendiri bangsa (Founding Fathers) Indonesia sebagai landasan berbangsa dan bernegara adalah salah satu hasil pikir yang mendalam para pemikir dan pemimpin calon pendiri bangsa Indonesia saat itu. ${ }^{6}$ Undang-Undang Dasar 1945 Negara Kesatuan Republik Indonesia (UUD NKRI) secara tegas menjamin kebebasan beragama dan berkeyakinan. Hal ini tertuang pada Pasal 28 E bahwa, "Setiap orang bebas memeluk agama dan beribadat menurut agamanya.." dan "Setiap orang berhak atas kebebasan meyakini kepercayaan. ." Pada prinsipnya hak ini merupakan sebuah non derogable rights atau hak yang tidak dapat dikurangi. Pasal 29 Undang-Undang Dasar NRI 1945 juga menyatakan, "Negara menjamin kemerdekaan tiap-tiap penduduk untuk memeluk agamanya masing-masing dan untuk beribadat menurut agamanya dan kepercayaan itu". ${ }^{7}$

5 Declaration of Human Rights (UDHR), 1948

Article 2

Everyone is entitled to all the rights and freedoms set forth in this Declaration, without distinction of any kind, such as race, colour, sex, language, religion, political or other opinion, national or social origin, property, birth or other status. Furthermore, no distinction shall be made on the basis of the political, jurisdictional or international status of the country or territory to which a person belongs, whether it be independent, trust, non-self-governing or under any other limitation of sovereignty.

Article 18

Everyone has the right to freedom of thought, conscience and religion; this right includes freedom to change his religion or belief, and freedom, either alone or in community with others and in public or private, to manifest his religion or belief in teaching, practice, worship and observance.

6 Amin Abdullah, Kebebasan Beragama atau Berkeyakinan dalam Perspektif Kemanusiaan Universal, Agama-agama, dan Keindonesiaan, 2011, Makalah dari Training HAM lanjutan Untuk Dosen Hukum dan HAM, Yogyakarta, hIm. 14

7 Diolah dari sebuah jurnal yang ditulis oleh Nicola Colbran dan diterjemahkan oleh Dr. Rahayu $\mathrm{SH}, \mathrm{MH}$ yang berjudul: Kebebasan Beragama 
Kebebasan beragama dan berkeyakinan juga telah dijamin oleh sistem perundang-undangan di Indonesia. Hal ini dinyatakan pada UndangUndang No. 39 Tahun 1999 tentang Hak Asasi Manusia Pasal 22 ayat (1) dan (2) ${ }^{8}$ dan Piagam Indonesia tentang Hak Asasi Manusia yang disahkan oleh Majelis Permusyawaratan Rakyat melalui keputusannya No. VII/MPR/1998 ysng menegaskan hak setiap orang untuk bebas memeluk agamanya masing-masing dan beribadat menurut agamanya dan kepercayaannya itu

Meskipun kebebasan beragama secara jelas telah diatur di dalam konstitusi dan perundangan nasional Indonesia, namun ternyata masih terdapat banyak kasus pelanggaran hak asasi manusia sebagai akibat pembatasan hak-hak kebebasan beragama dan berkeyakinan, baik yang dilakukan oleh pemerintah maupun dilakukan oleh penduduk di Indonesia. Gangguan terhadap pelaksanaan kebebasan beragama juga dialami oleh masyarakat ketika mereka dianggap sebagai penganut aliran/mahzab yang berbeda meskipun dalam agama yang sama. Hal ini terjadi pada masyarakat Muslim Syiah. Pada akhir tahun 2011 di Sampang, Madura terjadi konflik antar aliran/mahzab Islam Sunni dan Syiah yang dipicu oleh masalah keluarga, dan perebutan wilayah pendukung pencalonan pilkada setempat.

Meskipun sempat mereda, konflik ini muncul lagi pada pertengahan bulan Juli 2012 lalu. Konflik yang terjadi pada bulan Juli 2012 tersebut diduga dipicu oleh pengesahan Fatwa MUI pada tanggal 27 Januari 2012 lalu, MUI mengesahkan Keputusan Fatwa MUI Propinsi Jawa Timur, dengan nomor putusan No. Kep-01/SKF-MUI/ JTM/I/2012, Tentang Kesesatan Ajaran Syiah. ${ }^{9}$ Dikeluarkannya Fatwa MUI yang menyesatkan

atau Berkeyakinan Di Indonesia: Jaminan Secara Normatif dan Pelaksanaannya Dalam Kehidupan Berbangsa dan Bernegara. hlm.2

8 Pasal 22 Undang Undang No. 39 Tahun 1999 Tentang Hak Asasi Manusia.

(1) Setiap orang bebas memeluk agamanya masing-masing dan untuk beribadah menurut agamnya dan kepercayaanya itu.

(2) Negara menjamin kemerdekaan setiap orang memeluk agamanya masing-masing dan untuk beribadat menurut agamanya 9 Loc.Cit. ajaran Islam Syiah ditakutkan banyak pihak akan memicu suatu konflik kekerasan antar umat beragama di banyak daerah di Indonesia.

Penelitianmerupakan suatusaranapokokuntuk menemukan jawaban dari berbagai persoalan. Penelitian pada hakekatnya mengungkapkan sesuatu secara sistematis, metodologis dan konsisten sehingga sudah semestinya hasil dari penelitian dapat dipertanggungjawabkan. ${ }^{10}$ Suatu penelitian hukum memerlukan adanya suatu metode penelitian agar penelitian tersebut mendapatkan data yang akurat serta memperoleh hasil yang dapat dipertanggungjawabkan kebenarannya. Pembuatan penulisan hukum ini penulis mengumpulkan, menyusun serta menyajikan data berdasarkan metode penelitian hukum agar penulisan ini menjadi fokus serta memenuhi persyaratan sebagai penulisan ilmiah. Suatu penelitian pada hakikatnya adalah aktivitas seseorang untuk mendapatkan kebenaran tentang sesuatu hal. Dalam dunia ilmu pengetahuan suatu penelitian tidak akan mendapatkan pencapaian yang maksimal bila penelitian tersebut tidak didukung dengan metode yang tepat dan benar.

Metode pendekatan yang digunakan dalam penelitian ini adalah yuridis normatif. Jenis penelitian hukum normatif adalah penelitian yang berdasarkan pada kaidah-kaidah hukum yang ada, sedangkan pendekatan yuridis adalah suatu pendekatan yang mengacu pada hukum dan peraturan perundang-undangan yang berlaku. ${ }^{11}$ Dengan demikian penelitian ini menggunakan pendekataan yuridis normatif dalam membahas permasalahan pelaksanaan perlindungan dan penjaminan terhadap kebebasann beragama dan berkeyakinan yang diatur di dalam konstitusi dan sistem perundang-undangan Indonesia serta bagaimana tanggung jawab negara terhadap konflik agama yang terjadi di daerah Sampang, Madura, Jawa Timur.

Spesifikasi penelitian dalam skripsi ini termasuk penelitian deskriptif analisis. Penelitian ini bersifat dekriptif maksudnya adalah bahwa penelitian ini bermaksud memberikan gambaran secara rinci, sistematis dan menyeluruh mengenai kronologis

10 Soerjono Soekanto dan Sri Mamudji, Penelitian Hukum Normatif, ( Jakarta : Rajawali, 1985), hlm 1

11 Ronny Hanitijo Soemitro , Metode Penelitian Hukum dan Jurimetri (Jakarta: Ghalia Indonesia, 1988), hal.2 
kejadian konflik agama yang terjadi di Sampang, Madura, serta bentuk pertanggungjawaban negara terhadap kasus pelanggaran HAM yang terjadi di Kota Sampang tersebut, baik dari segi pelaku maupun korban. Sedangkan analisis maksudnya adalah peneliti mengelompokkan, membandingkan dan meneliti gambaran-gambaran yang telah diperinci. Kemudian peneliti dapat menemukan kesimpulan-kesimpulan dari yang diteliti.

Dalam penelitian ini, data yang digunakan adalah data sekunder yang didapatkan melalui studi kepustakaan sesuai dengan metode pendekatan yang dipakai. Sumber data yang diperoleh melalui studi kepustakaan dengan mempelajari literatur, dokumen resmi, peraturan perundang-undangan dan keputusan hakim/ yurisprudensi yang berkaitan dengan obyek yang diteliti. Data sekunder dapat diperoleh melalui :

\section{B. PEMBAHASAN}

\section{Kebebasan Beragama sebagai bagian dari Hak Asasi Manusia.}

HAM mulai mendapat perhatian di dunia internasional sejak tahun 1225 yaitu pada saat ditandatanganinya Magna Charta oleh Raja John of England. Magna Charta adalah sebuah piagam yang dikeluarkan oleh pemerintahan Inggris pada tanggal 15 Juni 1225 . Lahirnya piagam ini sebenarnya merupakan penggambaran betapa rendahnya tingkat apresiasi terhadap hak asasi manusia pada jaman dahulu. Magna Charta menunjukkan bahwa HAM adalah suatu kepentingan mendasar dalam hal penghormatan terhadap nilai-nilai kemanusiaan, khususnya kepada penghormatan hak-hak kebebasan dalam memeluk agama. Hal ini terbukti dengan dicantumkannya didalam Klausula Pertama Magna Charta mengenai pemberian kebebasan kepada Gereja, dan kebebasan kepada Gereja tidak dapat diganggu gugat oleh siapapun (termasuk Kerajaan Inggris) selamanya. Hal ini membuktikan tentang penghormatan kepada hak-hak keagamaan pada saat itu.

Pengakuan mengenai hak-hak kebebasan beragama dan memeluk aliran kepercayaan terus berkembang di seluruh belahan dunia. Perjuangan hak asasi manusia di Prancis dirumuskan dalam suatu naskah pada awal Revolusi Prancis. Perjuangan itu dilakukan untuk melawan kesewenang-wenangan rezim lama. Naskah tersebut dikenal dengan Declaration Des Droits De L'Homme et Du Citoyen yaitu pernyataan mengenai hak-hak manusia dan warga negara. Di Amerika pengakuan mengenai kebebasan tersebut diperjuangkan dengan hasil nyata yang tercantum didalam Declaration of Independence of United State of America 1776. Deklarasi kemerdekaan Amerika tersebut lahir dari interpretasi tentang rumusan dasar mengenai hak-hak kebebasan manusia, yaitu hak untuk hidup, Hak untuk mendapat kebebasan dan hak untuk dapat memiliki (Life, Liberty, Estate).

Perkembangan Konstitusi Indonesia mulai dari UUD 1945, Konstitusi RIS, UUDS 1950, hingga UUD NKRI 1945 amandemen keempat, konsep dari konstitusi yang dibawa Indonesia tidak pernah meninggalkan pengakuan dan perlindungan terhadap kebebasan beragama. Hal tersebut diikuti dengan sejumlah tata perundang-undangan yang melindungi HAM, beberapa diantaranya adalah Undang-Undang No. 39 Tahun 1999 Tentang Hak Asasi Manusia, Undang-Undang No. 23 Tahun 2002 Tentang Perlindungan Anak, Undang-Undang No. 9 Tahun 1998 Tentang Kemerdekaan Menyampaikan Pendapat di Muka Umum, dan sebagainya. Penerbitan Undang-Undang yang melindungi HAM di Indonesia merupakan bentuk dukungan dan pengakuan pemerintah Indonesia terhadap segala bentuk HAM serta merupakan perwujudan tanggung jawab negara dalam memberikan perlindungan HAM terhadap warga negaranya.

Perjuangan terhadap HAM mulai dari Tahun 1225 hingga pengakuan terhadap HAM didalam konstitusi Indonesia memiliki corak yang menarik yaitu mengenai persamaan hak terhadap pemeluk agama dan keyakinan yang berbeda, kebebasan untuk berpendapat, kebebasan untuk menentukan nasib dan tuntutan terhadap persamaan hak lainnya. Oleh karena itu kebebasan beragama dan berkeyakinan merupakan hak asasi manusia yang paling mendasar, melekat pada tubuh 
manusia dan tidak dapat dipisahkan oleh siapapun dan oleh apapun.

\section{Implementasi dari prinsip kebebasan beragama dan berkeyakinan dalam kasus di Sampang.}

Berdasarkan data yang diperoleh dari laporan The Asian Muslim Action Network (AMAN) Indonesia dalam judul Dilema Kebebebasan Beragama di Indonesia: Studi Kasus Pembakaran Rumah Ibadah di Sampang Madura, makna yang terjadi terhadap kaum Syiah adalah bukti negara kembali mengabaikan prinsip HAM (dalam hal ini implementasi mengenai pemahaman kebebasan beragama dan berkeyakinan).

Aparat keamanan tidak bertindak atau melakukan pembiaran (omission) pada saat terjadi kerusuhan. Hal tersebut terlihat dari adanya korban yang meninggal, jumlah korban luka-luka serta rumah warga yang dibakar oleh sekelompok masyarakat.

Tanggung Jawab Negara c.q Pemerintah Indonesia Terhadap Pelanggaran Prinsip Kebebasan Beragama di Sampang.

Sampai saat ini tanggung jawab moral yang sudah seharusnya menjadi hak para korban kerusuhan Sampang belum juga diterima sepenuhnya oleh para korban. Sesuai dengan isi Deklarasi Prinsip-Prinsip Dasar Keadilan Bagi Para Korban Kejahatan dan Penyalahgunaan Kekuasaan (The Declaration of Basic Principles of Justice for Victims of Crime and Abuse of Power) Resolusi Majelis Umum Perserikatan Bangsa-Bangsa No. 40/34 tertanggal 29 November 1985. Deklarasi tersebut mengandung ketentuan-ketentuan sebagai berikut : ${ }^{12}$

1. Para korban berhak mendapatkan penggantian segera atas kerugian yang diderita.

2. Mereka harus diberitahu tentang hak mereka untuk mendapat penggantian.

3. Bilamana kompensasi tidak sepenuhnya didapat dari pelaku atau sumber-

12 A/RES/40/34/29 November 1985/96th plenary meeting/Declaration of Basic Principles of Justice Victims of Crime and Abuse of Power diunduh dari http://www.un.org/documents/ga/res/40/a40r034. htm pada tanggal 1 Januari 2013 pukul 03.15 WIB. sumber lainnya, negara harus berusaha menyediakan kompensasi keuangan.

4. Para korban harus mendapat dukungan dan bantuan material, pengobatan psikologis dan sosial yang diperlukan. Selain itu, tanggung jawab negara terhadap pelaku kerusuhan adalah memberikan ketegasan hukum kepada semua pelaku kerusuhan dan dalang dibalik kerusuhan tersebut, serta memberikan sanksi tegas kepada aparat pemerintah yang membiarkan terjadinya kerusuhan pelanggaran HAM tersebut dan kepada pemerintah daerah serta lembaga-lembaga keagaman daerah Sampang yang mengeluarkan keputusan yang bersifat diskriminatif dan provokatif.

\section{SIMPULAN}

Berdasarkan uraian-uraian yang telah dijabarkan pada bab sebelumnya maka dapat ditarik kesimpulan bahwa :

1. Sejarah perkembangan HAM di dunia serta perkembangan HAM di dalam konstitusi Indonesia menunjukan bahwa pengakuan terhadap kebebasan beragama dan berkeyakinan merupakan bagian tak terpisahkan dari HAM. Seperti hak untuk hidup, hak terhadap kebebasan beragama merupakan suatu hak yang tidak dapat dipisahkan maupun dialihkan (non-derogable rights) dan melekat ketika manusia lahir di dunia.

2. Meskipun Negara menjamin implementasi dari prinsip kebebasan beragama dan berkeyakinan pada Pasal $28 \mathrm{E}$ ayat (1) dan (2) UUD NRI 1945, Namun yang terjadi pada kasus Sampang aparat keamanan tidak bertindak atau melakukan pembiaran (omission) pada saat terjadi kerusuhan. Selain itu, sikap pemerintah yang memicu provokasi ditunjukkan oleh MUI yang mengeluarkan keputusan yang menyatakan Syiah yang diajarkan oleh Tajul Muluk adalah sesat. Hal ini justru bertentangan dengan Pasal 18 ayat (4) ICCPR yang menyatakan negara seharusnya melindungi kebebasan warga negaranya dalam beragama dan berkeyakinan termasuk didalamnya tata 
cara beribadah.

3. Tanggung jawab pemerintah Indonesia dalam kasus Sampang tertuang pada Undang-Undang No. 26 Tahun 2000 Tentang Pengadilan HAM dalam Pasal 34 ayat (1) dan (2) yang menjelaskan bahwa Setiap korban dan saksi dalam pelanggaran hak asasi manusia yang berat berhak atas perlindungan fisik dan mental dari ancaman, gangguan, teror, dan kekerasan dari pihak manapun. Perlindungan tersebut disediakan cuma-cuma oleh aparat penegak hukum dan aparat penegak kemanan. Akan tetapi pada kenyataannya yang terjadi di konflik Sampang justru aparat keamanan tidak bertindak apa-apa atau melakukan pembiaran (omission) pada saat terjadi kerusuhan dan sampai sekarang rehabilitasi mental dari korbankorban kerusuhan Sampang masih belum direalisasikan oleh pemerintah. Selain itu, tanggung jawab negara terhadap pelaku kerusuhan, menjatuhkan hukuman pidana kepada semua pelaku kerusuhan dan dalang dibalik kerusuhan tersebut, serta memberikan sanksi tegas kepada aparat pemerintah yang membiarkan terjadinya kerusuhan pelanggaran HAM tersebut belum juga direalisasikan.

\section{Daftar Pustaka}

Al Khanif, 2010, Hukum dan Kebebasan Beragama Di Indonesia. (Yogyakarta: LaksBang Mediatama).

Black's Law Dictionary Edisi ke 4, 1990, (St. Paul. Minn: West Publishing)

Hasibullah Sastrawi, 2011, Ahmadiyah dan Keindonesiaan Kita, (Jakarta: Pustaka Masyarakat Setara)

Ifdhal Kasim, 2005, "Konvensi Hak Sipil dan Politik; Sebuah Pengantar", dalam Seri Bacaan Khusus HAM untuk Pengacara X, (Jakarta; Elsam)

John Kelsay, Summer B.Twiss, 2007, Religion and Human Rights, Ahmad Suaedy (terj.),(Yogyakarta: Institut Dian)

Moh Mahfud MD, 2006, Membangun Politik Hukum, Menegakkan Konstitusi, (Jakarta: Pustaka LP3ES Indonesia)

M.Noor Matdawam, 1989, Pembinaan dan Pemantapan Dasar Agama (Aqidah Islamiyah), cet. II (Yogyakarta: Bina Karier)

Muladi, 1997, Hak Asasi Manusia, Politik Dan Sistem Peradilan Pidana. (Semarang: Badan Penerbit Universitas Diponegoro)

Rahayu, 2010, Hukum Hak Asasi Manusia (HAM), (Semarang: Badan Penerbit Universitas Diponegoro)

RM. A.B. Kusuma, 2004, Lahirnya Undang-Undang Dasar 1945, (Jakarta: Badan Penerbit Fakultas Hukum Universitas Indonesia)

Ronny Hannitijo Soemitro, 1981, Pengantar IImu Hukum, (Jakarta : Galia Indonesia)

Ronny Hanitijo Soemitro, 1988, Metode Penelitian Hukum dan Jurimetri (Jakarta: Ghalia Indonesia)

Soerjono Soekanto dan Sri Mamudji, 1985, Penelitian Hukum Normatif, ( Jakarta: Rajawali)

Theo van Boven, 2001, Study Concerning The Right to Restitution, Compensation and Rehabilitasion for Victims of Gross Violations of Human Rights and Fundamental Freedoms, Eddie Sius R. Laggut (Ed.), (Jakarta: ELSAM) 